\title{
20 let Fakulty financí a účetnictví Vysoké školy ekonomické v Praze
}

Vážení čtenáři,

pokud u nás hovoříme o stáří univerzity, každému se v paměti asi vybaví rok 1348, který jsme si na hodinách dějepisu nesmazatelně spojili se založením Karlovy univerzity. Při srovnání s tímto letopočtem se může zdát rok 1991, ve kterém byla založena Fakulta financí a účetnictví, sice jako včera, ale důvod k určitému ohlédnutí to nesporně je.

Vznik Fakulty byl výsledkem porevolučních změn na Vysoké škole ekonomické. Základ nové fakulty byl položen na dvou tehdejších velkých katedrách - katedře financí a úvěru a katedře účetnictví, které do té doby působily na různých fakultách. Zatímco katedra financí a úvěru byla součástí národohospodářské fakulty, katedra účetnictví spadala pod do té doby existující fakultu řízení. Součástí nové fakulty se stala z důvodů tradičních odborných i personálních vazeb i katedra didaktiky ekonomických předmětů.

Nápad vytvořit zcela novou fakultu založenou na propojení financí a účetnictví byl poměrně odvážný. Role financí i účetnictví v centrálně plánované ekonomice byla významně potlačená, a tudíž nejen zájem studentů, ale i přijetí fakulty odbornou a laickou veřejností bylo velkou neznámou.

Již záhy po založení fakulty se ukázalo, že tento krok byl více než správný. Fakulta se rychle dostala do povědomí jako jedna z předních ekonomických fakult u nás, po studijních oborech nabízených fakultou byla vysoká poptávka a řada pracovníků fakulty se významně podílela i na ekonomické transformaci a formování nového ekonomického systému v Československu.

Hlavní důvody úspěšného rozvoje fakulty lze hledat ve dvou oblastech. Na jedné straně to bylo propojení dvou disciplín - financí a účetnictví - které začaly po letech živoření hrát zásadní úlohu v ekonomice a jejichž znalost byla předpokladem pro pochopení fungování tržní ekonomiky. Absence znalosti obou těchto disciplín u široké odborné veřejnosti na straně jedné a jejich nezbytnost pro každého ekonoma v podmínkách tržní ekonomiky na straně druhé, byly příčinou vysokého zájmu jak o prezenční formy studia, tak i řadu postgraduálních kurzů určených pro absolventy vysokých škol ze socialistické éry.

Ještě zásadnější roli však sehráli lidé, na kterých stály obě katedry a kteří se posléze stali i čelnými představiteli nově vzniklé fakulty a jejích kateder. I přes dlouholetou izolaci od západní ekonomické teorie i praxe byli schopni velmi rychle zformovat obsah studijních oborů vycházející ze standardního pojetí financí a účetnictví, připravit nové učebnice a navázat mezinárodní kontakty. Výčet jmen všech, kteří se o zrod nové fakulty zasloužili, by byl velmi dlouhý, za všechny je na místě uvést alespoň prof. Vladimíra Pilného, který byl na jaře $\mathrm{v}$ jednadevadesátém roce zvolen do čela fakulty jako její první děkan.

Úspěšný dvacetiletý rozvoj fakulty lze především dokládat na stovkách absolventů, kteří se

dokázali prosadit na nejrůznějších místech. Fakulta se dlouhodobě může pochlubit 
prakticky nulovou nezaměstnaností svých absolventů, kteří navíc velmi pozitivně hodnotí to, jak je fakulta připravila na budoucí zaměstnání. Je zřejmé, že dobře připravené absolventy může vychovávat pouze kvalitní škola se stabilním týmem vysoce erudovaných odborníků uznávaných jak vakademické sféře, tak i v ekonomické praxi. Jen díky jim má fakulta akreditaci na všechny tři typy studia, rovněž tak i pro habilitační a profesorská řízení. Nelze ani opomenout, že se fakulta každoročně umíst'uje na předních místech $\mathrm{v}$ žebříčku ekonomických fakult, který se v posledních letech u nás sestavuje .

Dvacetiny v životě člověka obvykle znamenají, že přicházejí nejlepší léta, kdy má chut' měnit svět, prosadit se a něco dokázat. Jak jsem již naznačil v úvodu, dvacetiny v životě školy představují pouze první vykročení na cestě budování její tradice a pevného místa v konkurenci jiných škol. Nicméně určitě i naší fakultě nechybí chut' posílit své dobré jméno na domácím i mezinárodním poli. Předpoklady k tomu díky svým akademickým pracovníkům, ale i studentům fakulta určitě má. A byla by velká škoda, pokud by je nedokázala využít. Koneckonců je to i naše povinnost vůči těm, kteří před dvaceti lety naši fakultu zakládali.

\author{
doc. Ing. Petr Dvořák, Ph.D. \\ děkan \\ Fakulty financí a účetnictví \\ Vysoké školy ekonomické v Praze
}

